\title{
Needs Analysis of Childrens' Right Curriculum for Parenting Education
}

\author{
Sri Nurhayati, ${ }^{1, *}$, Wellanda Alby Nugraha ${ }^{2}$, Hani Solihah ${ }^{3}$ \\ ${ }^{1,2}$ IKIP Siliwangi, Cimahi, Indonesia \\ ${ }^{3}$ STAINU Tasikmalaya, Tasikmalaya, Indonesia \\ *Corresponding author.Email: srinurhayati@ikipsiliwangi.ac.id
}

\begin{abstract}
This research aims to find out the initial need for children's rights and how to fulfil children's rights in accordance with the mandate of the Child Protection Act and Islamic Law for the curriculum of parenting education programs. The explanation of the child's rights is an important knowledge for parents. The method used in this study is a case study on 100 parents in Cimahi City with purposive sampling techniques in determining respondents. The number of respondents was 100 parents who had children aged 0-18 years. Data collection techniques use interviews and observations as well as secondary data. This study found that: 1) parents have learned about a child's rights either under existing law or from the perspective of Islamic law, but still cannot fulfil it. 2) Curriculum of parenting programs refers to the rights of children in accordance with the Child Protection Act and the rights of children according to the perspective of Islamic law includes the correct paradigm of children, cultivating talents and encouraging children's natural potential, cultivating the roles of fathers and mothers as teachers for children, giving children and preparing children to be fair and civilized adults.
\end{abstract}

Keywords: Children's rights, parenting education program curriculum, needs analysis.

\section{INTRODUCTION}

Children, like all human beings, have human rights but certain rights are specific to children [1]. Children should be active participants in development processes that affect their lives, not passive development recipients whose interventions are understood and implemented by development agencies [2].

In reality, violence and other wrong behaviour towards children often occur. As a weak being, children are often victims of violence, both physical, psychic, sexual, economic, etc. The perpetrators of child abuse are usually the people around them. It is not uncommon for perpetrators to be the people who are supposed to provide protection to them, such as the elderly [3].

Children are easily victimized for their helplessness in the face of their neglect, abuse, persecution, and ignorance. Whereas children's lives are not private affairs but public affairs that can be fulfilled by fostering children's rights [4].

This research aims to find out the initial needs of the child rights curriculum for the implementation of parenting education. The explanation of the child's rights is an important knowledge for parents. Like other knowledge, children's rights also need to be learned in a planned and programmed manner. A curriculum with the basic purpose of providing parents with an understanding of children's rights can be developed and content and teaching learning activities can be fully established and prepared to help parents understand the rights of the child and know how to fulfil those rights. Therefore, before developing a curriculum, it is necessary to study the needs analysis to know the need for the needs of the curriculum.

Needs analysis is the first step in designing the curriculum in order to provide validity and relevance for the sustainability of curriculum design activities to determine real needs through information gathering activities [5], [6]. Once identified, the need can be the basis for designing tests, compiling materials, designing learning activities, and evaluating strategies, as well as to re-evaluate the accuracy and accuracy of actual needs analysis as a process of planning and preparing educational activities for the curriculum [7].

Before developing the curriculum, the needs analysis put forward how important the curriculum is and alleviated the whole curriculum development process by setting curriculum objectives. The importance of needs analysis measures has been emphasized in previous curriculum development studies $[8,9,10]$. Determining whether the curriculum of children's rights, which is considered an important value in the relevant literature, 
should be taught will explain the curriculum of prospective children's rights. In the parenting process, parents should be given an understanding of the rights of the child to provide awareness for the parent that the child has rights to be fulfilled, so it is important to determine the educational needs of parenting on this issue. Therefore, the purpose of this research is to know the needs and expectations of parents on how to become parents who can fulfil the rights of children who are packaged into the curriculum in the parent's education program in Cimahi City, Indonesia.

\section{CHILDREN'S RIGHTS}

UNICEF explains that children are immature individuals both physically, mentally and socially. Due to its vulnerable condition, it depends on others and is still in the process of development. Children compared to adults are more at risk of crimes such as physical and psychic violence, abuse, exploitation and other crimes, so children need to be protected [11]. Children's rights are essentially part of human rights that must be guaranteed, protected, and fulfilled by parents, families, communities, governments, and countries. Children are one of the most vulnerable groups in almost all populations because of their physical and emotional dependence on adults and social status.

For ten years the discussion of children's rights has been of concern to the world. Representatives of national governments, UN agencies and NGOs continue to discuss reaching an agreement on the content of the Convention on The Rights of The Child (CRC) which was finally agreed in 1989 [12], [13], [14]. CRC is intended to ensure children obtain their rights under any circumstances and conditions [15]. There are four core principles of the convention: non-discrimination, the best interests of the child, the right to life, survival, and development, and respect for the views of the child [1].

In Indonesia the rights of the child have been stipulated in Law No. 22 of 2002 on Child Protection which explains that child protection is all activities to guarantee and protect the child and its rights in order to live, grow, develop and participate optimally in accordance with the dignity and dignity of humanity, as well as to be protected from violence and discrimination. Through the act, the rights of the child are explained to include: 1) living, growing, developing and participating in accordance with the dignity and dignity of humanity, as well as being protection from violence and discrimination; 2) have a name and identity; 3) worship according to his religion, think and express; 4) knowing, being raised, and being raised by his own parents; 5) obtain health and social security services; 6) obtain education and teaching, as well as protection from sexual crimes and violence in the education unit; 7) express and be heard his opinion, receive, seek, and provide information; 8) rest and make the most of your free time, hang out with your peers, play, relax, and get creative; 9) children with disabilities are entitled to rehabilitation, social assistance, and maintenance of social welfare standards; 10) protection from: a) discrimination; b) exploitation; c) release; d) cruelty, violence, and persecution; e) injustice; and f) other mistreats; 11) protection from: a) abuse in political activities, involvement in armed disputes, social unrest, events containing elements of violence, warfare, and sexual crimes; 12) protection from targets of persecution, torture, or inhuman punishment; 13) obtaining freedom and treatment according to the law [16].

Furthermore, Law No. 22 of 2002 was updated to Law No. 35 of 2014 [17]. According to the law, children's rights can be grouped into four categories, namely: 1) survival rights, 2) protection rights, 3) development rights, 4) participation rights, and 5) identity rights.

Aside from the rights of children stipulated in the legislation in Indonesia, other things that need to be looked at are concerning the welfare of the child. In measuring child welfare, indicators of child welfare identified in order to assess the child's welfare level are reviewed from various sides of life as stipulated in Law No. 35 of 2014 on Child Protection [18]. As can be seen through the following table.

Table 1. Risks and Needs of Children's Lives by Level of Life's Development

\begin{tabular}{|l|l|l|l|l|l|}
\hline \multirow{2}{*}{ Age range } & \multicolumn{5}{|c|}{ Dimensions of Indonesian child rights } \\
\cline { 2 - 6 } & Survival of Life & Protection & Development & Participation & Identity \\
\hline $\begin{array}{l}\text { New-born } \\
(0-11 \text { month })\end{array}$ & Mortality & $\begin{array}{l}\text { Pregnancy } \\
\text { Monitoring }\end{array}$ & Nutrition Status & $\begin{array}{l}\text { Mother's marriage } \\
\text { certificate }\end{array}$ \\
\hline $\begin{array}{l}\text { Toddler } \\
(1-4 \text { month })\end{array}$ & Mortality & Immunisation & Nutrition Status & Birth certificate \\
\hline $\begin{array}{l}\text { Child } \\
(5-11 \text { month })\end{array}$ & Mortality & $\begin{array}{l}\text { Working, Early } \\
\text { Marriage }\end{array}$ & School participation & $\begin{array}{l}\text { Tourism, social } \\
\text { activities }\end{array}$ & Birth certificate \\
\hline $\begin{array}{l}\text { Adolescent } \\
(12-14 \text { year old })\end{array}$ & Morbidity & $\begin{array}{l}\text { Working, Early } \\
\text { Marriage }\end{array}$ & School participation & $\begin{array}{l}\text { Tourism, social } \\
\text { activities }\end{array}$ & Birth certificate \\
\hline $\begin{array}{l}\text { Adolescent } \\
(15-17 \text { year old })\end{array}$ & Morbidity & $\begin{array}{l}\text { Working, Early } \\
\text { Marriage }\end{array}$ & School participation & $\begin{array}{l}\text { Tourism, social } \\
\text { activities }\end{array}$ & Birth certificate \\
\hline
\end{tabular}


As a muslim-majority country, in addition to the laws of the State, Indonesia also has a law that is also one of the sources of national law namely Islamic law. Child protection in the perspective of Islamic law means the fulfilment of the rights of the child and its protection from things that could harm him. The rights of the child are clearly and detailed in Islamic law contained in the verses of the Quran and hadiths. The rights of the child in the perspective of Islamic law are: 1) the right to life; 2) obtain the recognition of offspring (nasab); 3) have a self-identity (good name); 4) get breast milk; 5) parenting and care; 6) cost of living (living); 7) education and teaching; 8) treated fairly [19].

From the above description, it appears that in general, the rights of children contained in the Child Protection Act are in line with the rights of the child in Islamic law. There is a difference between the Child Protection Act and Islamic law with respect to the right of the child, which is not alluded to the right of the child to obtain inheritance from his parents.

\subsection{Parenting Education}

Family is the first social environment known to children. Interactions between family members can raise self-awareness so that the child understands that he or she has an individual role and as part of a social being [20]. Parental education describes a series of teaching and support programs that focus on parenting skills, feelings, and tasks. Parental education describes a series of teaching and support programs that focus on parenting skills, feelings, and tasks. Parental education is aimed at people of all ages, with a focus on communication personal relationship skills above all else [21].

Parenting programs can be defined as efforts designed to facilitate parent-child relationships and equip parents with the skills needed to perform parenting roles [22].

Parenting is a complex and dynamic process. From that nurturing, children can learn about appropriate and inappropriate behaviours, experiences, right and wrong choices in making decisions, acquiring skills, and understanding roles and norms in society [10].

Parenting is an important element in a child's wellbeing. Good people are those who are able to give children the benefits of resilience, well-being, selfesteem, social complicity and citizenship values [23]. Differences in parenting goals will affect differences in parenting styles and parenting practices [24]. One of the basic aspects of the fostering pattern is influenced by various factors, such as attitudes and cultural ideology as a macro system [25].

While according to Cooper [26] the basic purpose of the parenting curriculum is to strengthen the family, helping it to be more effective in meeting the needs of each family member. This curriculum is expected to be achieved to meet the following objectives; 1 ) so that young mothers and fathers can make the transition and adapt well to parenthood; 2) so that young mothers and fathers are able to provide optimal care in the development of their children; 3 ) to have a mental, physical and emotional fit for the ability of the parent; 4) so that young mothers and fathers can plan and perform roles as workers, citizens, and parents; 5) so that young mothers and fathers can develop themselves mentally, physically, emotionally so as to successfully carry out their role as parents.

\section{METHOD}

This study uses a case study method because the study is focused on the opinions and thoughts of parents about efforts to fulfil the rights of the child. In addition, the analysis of needs is discussed in the relevant literature to apply a holistic approach in research. Sampling is done using a purposive sampling method to determine participants. The criteria used to choose parents are those who have children aged $0-18$ who are domiciled in Cimahi City. Study participants included 100 people who met these criteria.

The research data was collected through a semistructured interview form that had been prepared by the researchers. The interview form has 10 questions that include about the knowledge of the rights of the child, the fulfilment of the rights of the child, and their expectations on this issue.

Data analysis is done after all data is collected. Data obtained through observation is interpreted descriptively The data analysis model used is model Miles and Huberman [27] which includes data reduction, data presentation, and drawing conclusions. Data reduction is done by reducing, summarizing, or selecting data that fits the theme of the study. After that the data is presented in the form of a brief description, chart or table. The final step is to draw conclusions that will be proven by existing theories.

\section{RESULT AND DISCUSSION}

Based on interviews with parents about their knowledge of children's rights, $70 \%$ of the $100 \%$ of respondents replied that all they knew about children's rights included the right to live, to grow, to be happy, to love, to education, attention, guidance, and the right to obtain nutritious food.

In the context of the curriculum needs the child's rights have been governed by law and in the perspective of Islamic law. The rights of children under law no. 22 of 2006 are enhanced in law no. 35 of 2014: 1) survival, 2) protection, 3) development, 4) participation, and 5) identity. While in the Islamic legal perspective the rights of the child include: 1) the right to life; 2) obtain the 
recognition of offspring (nasab); 3) have a self-identity (good name); 4) get breast milk; 5) parenting and care; 6) cost of living (living); 7) education and teaching; 8) treated fairly [19]).

The analysis of the findings of the interview results is similar to the findings of the library review. Basically, parents already know about some of the rights of the child. But $95 \%$ of respondents said they had not been able to fulfil the child's rights. Parents feel they have not been able to provide happiness materially and have not fully fulfilled the child's education. In interviews parents are very much interested in getting a parenting education about the rights of the child and how to do it properly. Parents are then asked about what they need in parenting learning. $100 \%$ of respondents pointed out that children's rights and practical ways of promoting children's rights as one of the important curriculums that need to exist in parenting education. Other curriculum stipulated by respondents in the parenting program include how to communicate with the child and how to teach good manners to the child. With the implementation of the child rights curriculum to help the parent's parenting pattern, it aims to provide welfare for the child. the fulfilment of a child's rights affects the quality of life of the child which then determines the child's welfare level [18]. Child equality is defined as 'a child's system of life and livelihood that can ensure its growth and development reasonably, both spiritually, physically and socially. Means welfare can be interpreted as the fulfilment of the need to grow optimally, both physical needs in the form of clothing, food, housing, health, education, and environmental quality, as well as psychiatric needs such as happiness, security, and recognition.

The state is obliged to participate in promoting the welfare and needs of the child by supporting parents and caregivers [28]. A new movement towards parental education needs to be made to re-examine the principles that are the basis for the development of the parenting program curriculum. The profession as a parent is an adult job with little or no training provided in school. Demands for educational procedures always arise before there is material to supply this demand [29].

The curriculum of the parenting program refers to the rights of the child in accordance with the Child Protection Act and the rights of the child according to the perspective of Islamic law include the correct paradigm of the child, the development of talent and the development of the child's potential, the coaching of the role of father and mother as a teacher for the child, giving the child and preparing the child to be a just and civilized adult.

\section{CONCLUSION}

The welfare of the child is closely related to the fulfilment of the rights of the child by the adult. Parents need to be educated about the rights of the child and how to properly fulfil the child's rights. The analysis of children's rights under Islamic law and legal perspectives is known that children's rights consist of the right to life, the right to protection, the right to growth, the right to participation, and the right to self-identity. Based on the analysis, in the process of education parents need to include a study of children's rights into the parenting curriculum. Thus, the author recommends to the organizers of parenting education in either formal or informal institutions to be able to implement the curriculum of children's rights. As for the next study, researchers hope there is a study on the effect of implementing parenting education by implementing this child rights curriculum.

\section{REFERENCES}

[1] Gabel SG. Social protection and children's rights in developing countries. Journal of international and Comparative Social Policy. 2014;30(3):199-16.

[2] Nurick R, Johnson V. Putting child rights and participatory monitoring and evaluation with children into practice: some examples in Indonesia, Nepal, South Africa and the UK. PLA Notes. 2001;42:39-44.

[3] Rozak P. Kekerasan terhadap anak dalam rumah tangga perspektif hukum islam. Sawwa. 2013;9:4570.

[4] O'Neill O. Children's rights and children's lives. Ethics. 1988;98(3):445-63.

[5] Guven S, Ozturk A, Duman SN. Needs analysis of responsibility curriculum for primary school students. Educational Research and Research. 2016;11(19):1831-40.

[6] Li J. Needs analysis: An effective way in business English curriculum design. Theory and Practice in Language Studies. 2014;4(9):1869-75.

[7] Brown JD. Using surveys in language programs. Cambridge: Cambridge University Press; 2001.

[8] Caliskan N, Çangal Ö. Needs analysis in teaching Turkish to foreigners: The case of Bosnia Herzegovina. Abant İzzet Baysal Üniversitesi Eğitim Fakültesi Derg. 2016;13(2).310-34.

[9] Doğanay A, Demircioğlu T, Yeşilpınar M. A need assessment study for an interdisciplinary curriculum about nature of science for prospective elementary teachers. Turkish Studies. 2014;9(5):777-98.

[10] Kocer O. The first step in curriculum development: Needs and situation analysis in teaching Turkish as a 
foreign language. Egitim ve bilim- education and Science. 2013;38(169):159-74.

[11]Lestari R, Fachri Y. Implementasi konvensi internasional tentang hak anak (Convention on the Rights of the Child) di Indonesia (studi kasus: pelanggaran terhadap hak anak di provinsi Kepulauan Riau 2010-2015). Riau: Riau University. 2017.

[12] Cantwell N. Words that speak volumes. J Connors, J Zermatten, A Panayotidis. 2007;18:21-29.

[13]Detrick S, Doek JE, Cantwell N. The United nations convention on the rights of the child: a guide to the "travaux preparatoires". Dordrecht-Boston-London: Martinus Nijhoff Publishers; 1992.

[14] Office of the United Nations High Commissioner for Human Rights. Legislative History of the Convention on the Rights of the Child. New York: United Nation; 2007.

[15]Rozak P. Kekerasan terhadap anak dalam rumah tangga perspektif hukum islam. Sawwa. 2013;9:4570.

[16] Sholihah H. Perbandingan hak-hak anak menurut undang-undang nomor 23 tahun 2002 tentang perlindungan anak dan hukum islam. Al-Afkar, Journal for Islamic Studies. 2018;1(2, July):88-12.

[17]Undang-undang nomor 35 tahun 2014 tentang perubahan atas undang-undang nomor 23 tahun 2002 tentang perlindungan anak.

[18] Imawan W, Ahnaf A. Indeks komposit kesejahteraan anak. Jakarta: Kementerian Pemberdayaan Perempuan dan Perlindungan Anak Republik Indonesia; 2016.

[19] Sholihah H. Perlindungan anak dalam perspektif hukum islam. Al-afkar, Journal for islamic studies. 2018;1(1, January):38-56.

[20] Hasanah VR. Community-based parenting education program in improving parents' skills. In: 3rd International Conference on Early Childhood Education (ICECE 2016). Atlantis Press; 2016.

[21]Einzig H. Parenting education and support. New Direction and cCounseling. 1996;220-34.

[22] Braiden HJ, Mcdaniel B, Mccann M, Duffy J. A pilot study of the incredible years basic parenting programme with bereaved families. Journal of Children Services. 2011;6(3):141-55.

[23] Pérez JC, Cumsille P. Adolescent temperament and parental control in the development of the adolescent decision making in a Chilean sample. Journal Adolescent. 2012;35(3):659-69.

[24] Oates J. Supporting parenting. Vol. 5. The Open University; 2010.
[25] Abidin FA, Siregar JR, Joefiani P, Koesma RE. Parenting goals among moslem parents in Bandung, Indonesia. In: 3rd International Conference on Early Childhood Education (ICECE 2016). Atlantis Press; 2016.

[26] Bronfenbrenner U. Contexts of child rearing: Problems and prospects. American Psychologist. 1979;34(10):844-50.

[27] Cooper GC. Developing a parenting curriculum. School Health Review. 1973;4(6):32-4

[28] Miles MB, Huberman AM. Qualitative data analysis: An expanded sourcebook. Sage; 1994.

[29] Hodgkin R, Newel P. Implementation handbook for the convention on the rights of the child. New York: United Nations Publications; 2007.

[30] Charters JA. The construction of a curriculum for parental education. Education and Urban Society. 1928;17(5):350-56. 